\title{
油脂の嘹好性のメカニズムに関する研究
}

\author{
(平成 30 年度日本栄養・食糧学会奨励賞受賞)
}

\author{
松 村 成 暢 $*, 1,2$
}

(2018年 7 月 3 日受付 ; 2018 年 8 月 6 日受理)

\begin{abstract}
要旨：油脂を多く含む食品は魅力的なおいしさ（喏好性）を持つ。我々はこれまでの研究により脂肪酸結合 タンパク質 CD36 が舌の味細胞に発現していることを見出し，油脂が受容体を介して味細胞を刺激すること を示してきた。本研究では G タンパク共役型の脂肪酸受容体 GPR120 が舌の味細胞に発現していることを 新たに発見した。次に油脂の嗜好性の脳内メカニズムについて検討を行った。嗜好性の高い食品の摂取は脳 内で $\beta$ エンドルフィン分泌を促進することが知られている。そこで，マウスに油脂を摂取させ検討したとこ ろ, 脳内で $\beta$ エンドルフィンニューロンが活性化されることが明らかとなった。 $\beta$ エンドルフィンは快感を 生み出す神経ペプチドであることから, 油脂は CD36 と GPR120を介して味細胞を刺激し, 味覚神経を介し て脳内で $\beta$ エンドルフィン分泌を引き起こす。これが快感を生み出し, 油脂の高い喏好性の発生に関与する 可能性を示した。
\end{abstract}

キーワード : 油脂, 味細胞, 嗜好性, $\mathrm{G}$ タンパク共役型受容体, $\beta$ エンドルフィン

身体にとって必要なもの, 生理的欲求に合致する食物 の喏好性は高い。嗜好性は主に味覚と嗅覚をもとにして 感じられるが，この情報により動物は身体にとって必要 なものを積極的に摃取するのである。逆にまずいものは 当然避けられる。まずいということは食べるべきではな い，食べると危険なものをその食品は含んでいるという ことである。現代社会では安全の保証された食べ物は容 易に手に入れることができるため，いちいち考えること もなく安全な食べ物をとることはできる。しかし，われ われの祖先もそうであったように, 日々飢餓と隣合わせ の生活をしている野生動物にとって味覚, 嗅覚, そこか ら生じる嗜好性とは生死に関わる感覚ではないだろうか。

\section{1. 油脂の嗜好性}

油脂は栄養素としては最高の食事エネルギー源であ る。食事エネルギー密度という点では食品中で最も高い。 心臟や筋肉など持久的な活動のエネルギー源となる。そ して, 食用油脂に含まれる必須脂肪酸やいくつかの脂溶 性ビタミンは動物が自ら合成できないため食事により摂 取しなければならない。油脂は肥満という観点でとかく 悪者にされがちであるが動物にとって欠かすことができ ないものなのである。冒頭にも述べたように味が栄養素 の選択に重要な役割を果たしているのであれば，動物や
人間の舌が, 油脂に特別な受容, 認識機構を持っていて も不思議ではない。生存のために進化の過程においても 保存するべきもののはずである。しかし，これまで味細 胞に押いて受容体を介した油脂の化学受容が存在すると いう科学的な証明はなかった。また，味細胞においてど のような受容体が油脂を分子として認識しているのかも 不明であった。

油脂を含む食品は嗜好性が高い。しかしながら “油脂 に味はあるのか?’’という問題には未だに論争がある。 高度に精製された新鮮な食用油は無味無臭であり, 実際, 鼻をつまんで口にしても特に美味しいとは思えない。し かし，もし油脂に味がないのであれば大トロや霜降り肉 の美味しさをどう説明するのだろうか。フライドポテト やアイスクリームから脂肪分のみを除くとどうなるか想 像は容易である。

\section{2. 脂肪酸結合タンパク質の味蕾での発現}

消化管細胞には食事由来の油脂を識別する機構が存在 しており，味覚にも消化管細胞と共通した脂肪識別機構 が存在する。味細胞は消化管の上皮細胞が分化したもの であるという説や，味覚受容体やその下流の細胞内シグ ナル伝達分子も味細胞と同じものが消化管にも発現して (る ${ }^{122)}$ 。

\footnotetext{
* 連絡者・別刷請求先 (E-mail: sigenobu@kais.kyoto-u.ac.jp)

1 京都大学大学院農学研究科食品生物科学専攻栄養化学分野 (606-8502 京都府京都市左京区北白川追分町)

2 京都大学大学院農学研究科食品生物科学専攻食品生理機能学分野 (611-0011 京都府宇治市五ヶ庄)
} 


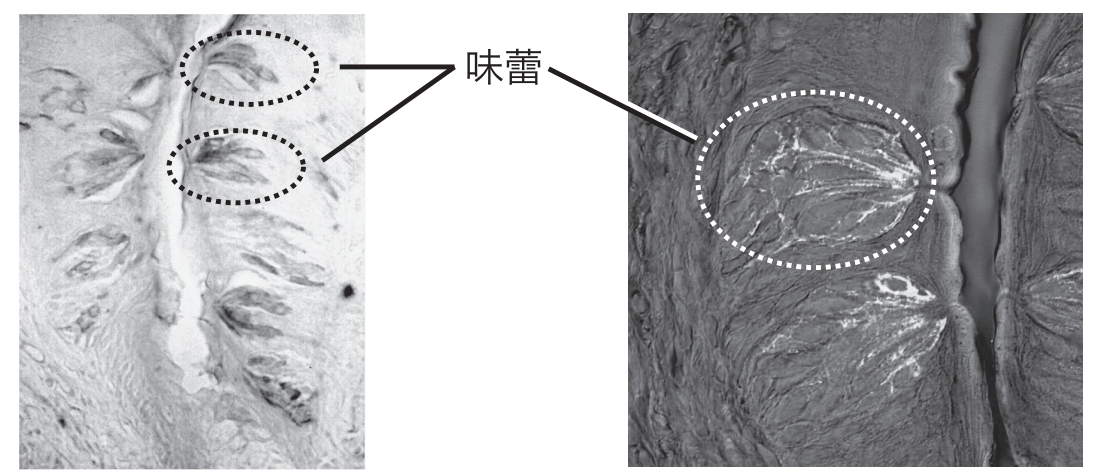

図 1 抗 CD36 抗体（左図）および抗 GPR120 抗体（右図）を用いたラッ 卜有郭乳頭の免疫染色像。味細胞特異的に強い染色が観察される（参考文 献 3）, 5）より一部改変)。

これまで我々の研究グループによりラット舌有郭乳頭 に脂肪酸輸送担体 (fatty acid transporter) CD36 mRNA が発現していることが世界ではじめて確認されだ)。北 海道大学岩永教授により免疫染色で CD36 が味細胞に強 く発現していることが明らかになった（図 1 左図）。

CD36 は小腸吸収上皮や, 筋肉, 脂肪組織, そしてマ クロファージなどの免疫細胞にも発現がみられる。小腸 上皮では脂肪酸取り込みとリンパ管へのカイロミクロン 放出に関与している。一方で筋肉や脂肪組織では CD 36 を介して取り込んだ脂肪酸は代謝や貯蔵にまわされるこ とから, 組織や細胞によってその役割は異なる。味細胞 において CD36 がどのように油脂を認識し, 下流へとシ グナルを伝達しているのかはいまだ不明である。味細胞 に発現している CD36 が筋肉や脂肪組織と同様に脂肪酸 輸送担体として食物中に含まれる脂肪酸の味細胞への取 り込みを行っているのか, もしくはこれとは異なり受容 体として機能しているのかは不明である。基本味の受容 体は細胞内カルシウムを増加させ, シグナルを伝達して いる。しかし, CD36が単独で細胞内カルシウムを増大 させるという報告はなく, おそらく他の分子と共役して 細胞内シグナル伝達を行っていると考えられる。

\section{3. 脂肪酸受容体 GPR120}

甘味や苦味などの基本五味に対する受容体は全て G タンパク共役型の受容体であるが CD36 は輸送担体であ る。そこで, $\mathrm{G}$ タンパク共役型の脂肪酸受容体の発現を 調べたところ GPR120 が舌の味蕾細胞に発現しているこ とを近年新たに発見した (図 1 右図 $)^{4) 5)}$ 。GPR120 は脂 肪酸の中でも主に多価不飽和脂肪酸に高い親和性を示す ことが報告されている ${ }^{6)}$ 。そこでマウスの脂肪酸に対す る啫好性を調べたところ, マウスも多価不飽和脂肪酸に 対して高い嗜好性を示すことが明らかとなった ${ }^{7)}$ 。 GPR120 は食事由来の脂肪を受容し, 消化管ホルモンの 分泌を促進する役割を担っている ${ }^{6)}$ 。この受容体が舌の 味細胞に発現しているということは, 味細胞には消化管 細胞と同様の手法で栄養素を認識する機構が備わってい
るということを示唆している。

\section{CD36 と GPR120}

GPR120 が味細胞に発現していることを発見した当初 は CD36と GPR120 は同じ細胞に発現し, 協調して機能 しているだろうと考えていた。しかしながら，実際には CD36 と GPR120 の両方を発現している味細胞は全体の $1 \%$ 前後しかみられず, ほとんどの味細胞がどちらか一 方の受容体を発現しているのみであった。これはCD36 と GPR120 が全く別経路で油脂を検知していることを示 すものである。CD36から得られる油脂の嗜好性と GPR120 から得られる油脂の嗜好性では質が異なるのか もしれない。

CD36 はスカベンジャーレセプターとして免疫細胞の マクロファージに発現がみられる。スカベンジャーレセ プターとはマクロファージの貪食に関わる受容体であ り, これを利用してマクロファージは体内に侵入してき た細菌に結合して細胞内に取り达む, つまり食べるので ある。一方で GPR120 もマクロファージで発現がみられ 脂肪酸受容体として機能し, 抗炎症性作用に関わる。つ まり，CD36 および GPR120 はマクロファージにおいて も油脂の検知, 領食に関わっているのである。単細胞レ ベル, 動物の個体レベルで油脂を検知し, 食べるという 行為が全く同じこれらの受容体を介して行われていると いう点で興味深い。おそらく単細胞生物が栄養素として 油脂を積極的に取り込む機構が哺乳類においても保存さ れているのではないだろうか。

\section{5. 油脂の嗜好性の脳内メカニズム}

マウスは油脂にたいして非常に高い嗜好性を示す（図 2)。また, 単に摂取量が多いのみならず, 非常に強い執 着がみられることがこれまでの研究より明らかとなって (る ${ }^{8) 9}$ 。そこで油脂摂取時に脳内のどこで何が起こっ ているのか検討を行った。嗜好性の高い甘味やアルコー ルの摂取は脳内で $\beta$ エンドルフィン分泌を促進すること が知られている。そこで, マウスに油脂を摂取させ実際 
に脳内で $\beta$ エンドルフィンニューロンが活性化されるの か検討を行った。マウスに油脂やスクロースなどを摃取 させたのちに脳を採取し，神経活性化マーカーである

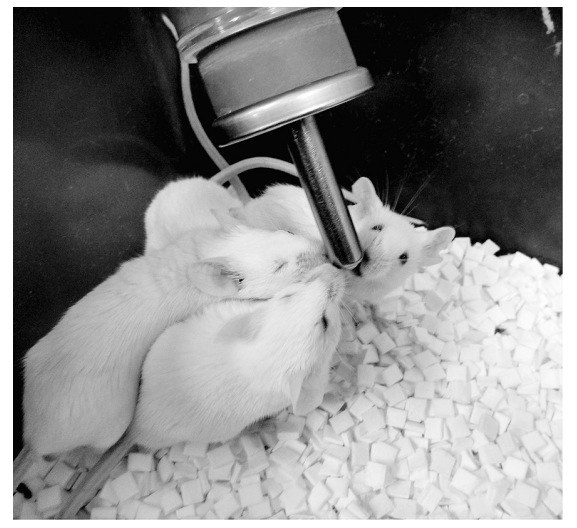

図 2 マウスは油脂に対して高い喏好性を示す。給水瓶 にコーン油を入れてマウスに与えると即座に寄ってきて 舐め始める。 $\mathrm{c}$-fos をもとに $\beta$ エンドルフィンニューロンの活性化状 態の検討を行った。油脂を摂取すると, $\beta$ エンドルフィ ンニューロン特異的に c-fos 発現の上昇が確認できた(図 $3 \mathrm{~A}, \mathrm{~B})^{10)}$ 。つまり油脂の摂取が $\beta$ エンドルフィンニュー ロンを活性化することが明らかとなった。さらに，他の 甘味などの味溶液と比較して油脂が最も強く $\beta$ エンドル フィンニューロンを活性化することが明らかとなった。 また，味覚神経を切除したマウスでは油脂摂取による $\beta$ エンドルフィンニューロンの活性化は起こらず, 油脂の 胃内投与でも変化はみられなかった（図 $3 \mathrm{C}, \mathrm{D})$ 。

\section{おわりに}

本研究成果により CD36に加えて GPR120 が舌上の味 細胞に発現していることが明らかとなった。現在では CD36 および GPR120 はともにマウスだけではなくヒト に挄ても味細胞で発現が確認されている ${ }^{11)}$ 。れれらの 受容体がヒトにおいても油脂の嗜好性に関与しているこ とを示唆するものである。しかしながら，この二つの受

A

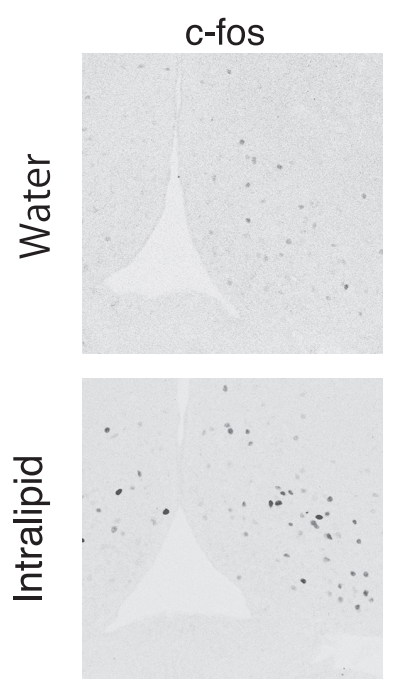

C

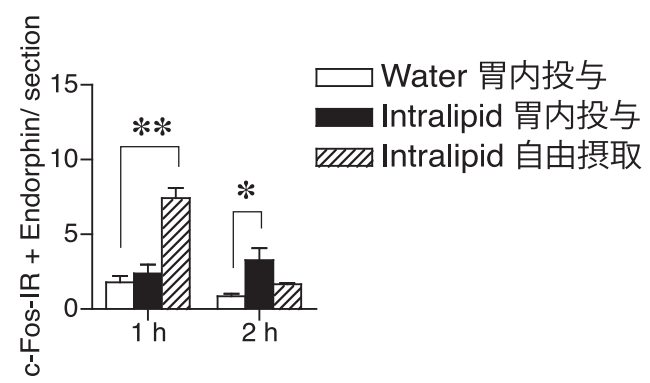

\section{Endorphin}
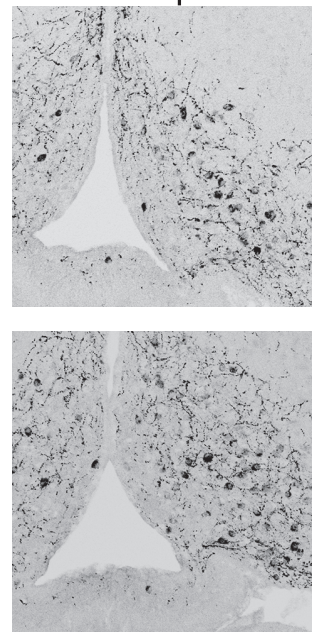

D

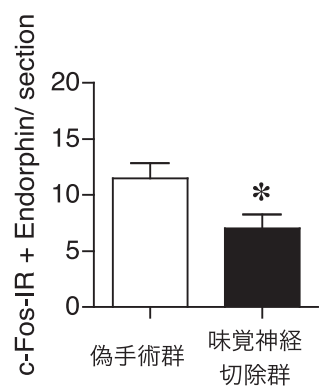

図 3 (A) 抗 c-fos 抗体㧍よび抗 Endorphin 抗体を用いたマウス脳視床下部免疫染色像。 イントラリピッド(乳化油脂)を摂取させると c-fos の発現が増加しているのが観察される。 (B) 各種溶液摄取後のエンドルフィンニューロンにおける c-fos 発現数。(C) 溶液を胃内 投与した場合と自由摂取させた場合の c-fos 発現数の比較。（D）味覚神経を切除したマウ スの c-fos 発現数の比較。(平均值 \pm 標準誤差。 $*: p<0.05, * *: p<0.01$ ) (参考文献 10）より一部改変)。 


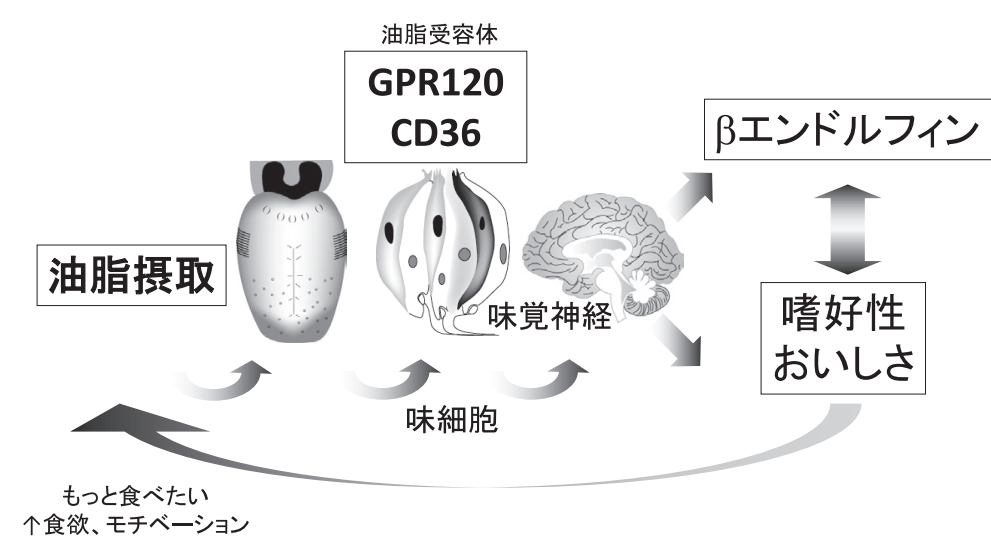

図 4 味細胞の脂肪受容体と $\beta$ エンドルフィンを介した油脂の嗜好 性のメカニズム

容体で油脂の嗜好性の全てを説明できるものではない。 実際，これらの受容体を欠損する動物では油脂の嗜好性 の低下が確認されるが喏好性が完全になくなることはな い。CD36 と GPR120 の二重欠損動物の実験はまだ行っ ていないが，これら以外の油脂に対する未知の受容体が 味細胞に発現するという可能性を否定することはでき ず，さらなる研究課題である。

本研究により, 油脂の摂取は $\beta$ エンドルフィンニュー ロンを特異的に活性化することが明らかとなった。これ らの結果をまとめると油脂は CD 36 および GPR120を介 して味細胞を刺激する。この情報は味覚神経を介して脳 内へと伝達され $\beta$ エンドルフィン分泌を引き起こす。こ れが快感を生み出し, 油脂の高い嗜好性の発生に関与す る可能性が示された（図 4)。本研究は京都大学動物実 験委員会㧍よび組換え DNA 実験安全委員会に本申請研 究に該当する計画を申請し, 審査を受け，倫理的に問題 がないことの承認を受けた上で, 適切な設備のある実験 施設において実験を行った。

\section{利 益 相 反}

本論文発表内容に関連して申告すべき COI 状態はない。

本稿を終えるにあたり，日本栄養・食糧学会奨励賞を 授与いただきましたことに対し，選考委員の先生方およ び関倸の先生方に厚く御礼申し上げます。本研究は, 京 都大学大学院農学研究科食品生物科学専攻栄養化学で行 われたものです。本研究を行うに際し, 学生時代よりご 指導ご鞭撻を賜りました伏木亨教授, 井上和生教授に心 より感謝申し上げます。また, 学部生時代に研究者とし ての基礎を教えていただき，長年にわたり激励とご助言 をいただいた大阪府立大学名誉教授中野長久教授ならび に大阪府立大学の乾博教授, 山地亮一教授, 共同研究者 として多大な協力をいただいた北海道大学岩永敏彦教授 に厚く御礼申し上げます。最後に, 本研究に関わりこれ まで支えてくれた京都大学栄養化学研究室学生諸氏に深 謝いたします。

\section{文献}

1) Lee AA, Owyang C (2017) Sugars, sweet taste receptors, and brain responses. Nutrients $9(7): 653$.

2) Niot I, Besnard P (2017) Appetite control by the tongue-gut axis and evaluation of the role of CD36/ SR-B2. Biochimie 136: 27-32.

3) Fukuwatari T, Kawada T, Tsuruta M, Hiraoka T, Iwanaga T, Sugimoto E, Fushiki T (1997) Expression of the putative membrane fatty acid transporter (FAT) in taste buds of the circumvallate papillae in rats. FEBS Lett 414 (2): 461-4.

4) Matsumura S, Mizushige T, Yoneda T, Iwanaga $T$, Tsuzuki S, Inoue K, Fushiki T (2007) GPR expression in the rat taste bud relating to fatty acid sensing. Biomed Res 28 (1): 49-55.

5) Matsumura S, Eguchi A, Mizushige T, Kitabayashi N, Tsuzuki S, Inoue K, Fushiki T (2009) Colocalization of GPR120 with phospholipase-Cbeta2 and alphagustducin in the taste bud cells in mice. Neurosci Lett 450 (2): 186-90.

6) Hirasawa A, Tsumaya K, Awaji T, Katsuma $S$, Adachi T, Yamada M, Sugimoto Y, Miyazaki S, Tsujimoto G (2005) Free fatty acids regulate gut incretin glucagon-like peptide-1 secretion through GPR120. Nat Med 11 (1): 90-4.

7) Yoneda T, Saitou K, Asano H, Mizushige T, Matsumura S, Eguchi A, Manabe Y, Tsuzuki S, Inoue K, Fushiki T (2009) Assessing palatability of long-chain fatty acids from the licking behavior of BALB/c mice. Physiol Behav 96 (4-5): 735-41.

8) Imaizumi M, Takeda M, Fushiki $T$ (2000) Effects of oil intake in the conditioned place preference test in mice. Brain Res 870 (1-2): 150-6.

9) Yoneda T, Taka Y, Okamura M, Mizushige T, Matsumura S, Manabe Y, Tsuzuki S, Inoue K, Fushiki T (2007) Reinforcing effect for corn oil stimulus was concentration dependent in an operant task in mice. Life Sci 81 (23-24): 1585-92.

10) Matsumura $S$, Eguchi A, Okafuji $Y$, Tatsu S, Mizushige T, Tsuzuki S, Inoue K, Fushiki T (2012) Dietary fat ingestion activates $\beta$-endorphin neurons in 
the hypothalamus. FEBS Lett $\mathbf{5 8 6}$ (8) : 1231-5.

11) Subramaniam $S$, Ozdener $M H$, Abdoul-Azize $S$, Saito K, Malik B, Maquart G, Hashimoto T, Marambaud P, Aribi M, Tordoff MG, Besnard P, Khan NA (2016)
ERK1/2 activation in human taste bud cells regulates fatty acid signaling and gustatory perception of fat in mice and humans. FASEB J 30 (10): 3489-500.

J Jpn Soc Nutr Food Sci 71: 231-235 (2018)

\section{Review}

\section{Study on the Mechanism of Dietary Fat Palatability \\ (Young Investigator Award of JSNFS (2018)) \\ Shigenobu Matsumura*,1,2}

(Received July 3, 2018; Accepted August 6, 2018)

Summary: Dietary fat is an attractive food component. Recent studies have suggested that chemical perception of fatty acid plays a role in the high palatability of fatty foods. Previously, we have found that the fatty acid transporter, CD36, is expressed in rodent taste bud cells, and recently we discovered that G-protein coupled receptor 120 (GPR120) is also expressed in taste cells. GPR120 is known to be a receptor for unsaturated fatty acid, and the mouse is a species known to have a marked preference for unsaturated fatty acids. These findings suggest that GPR120 might function as a sensor for dietary fat. It is well known that intake of palatable food stimulates $\beta$-endorphin release in the brain. We have found that dietary fat ingestion activates $\beta$-endorphin neurons in the hypothalamus via activation of taste nerves. Taste nerve transection surgery suppressed the activation of $\beta$-endorphin neurons resulting from dietary fat ingestion. Taken together, our present findings indicate that dietary fat may stimulate taste cells on the tongue through CD36 and GPR120, thus activating $\beta$-endorphin neurons in the brain. It is speculated that activated $\beta$-endorphin neurons release $\beta$-endorphin to promote consummatory behavior involving fatty foods.

Key words: dietary fat, taste cell, palatability, G-protein coupled receptor, $\beta$-endorphin

* Corresponding Author (E-mail: sigenobu@kais.kyoto-u.ac.jp)

${ }^{1}$ Laboratory of Nutrition Chemistry, Graduate School of Agriculture, Division of Food Science and Biotechnology, Kyoto University, Oiwakecho, Kitashirakawa, Sakyo-ku, Kyoto 606-8502, Japan

${ }^{2}$ Laboratory of Physiological Function of Food, Graduate School of Agriculture, Division of Food Science and Biotechnology, Kyoto University, Gokasho, Uji, Kyoto 611-0011, Japan 